\title{
Family vs Discourse
}

\section{Родина vs дискурс}

\section{Oxana Brovkina}

Ph.D. in Philology,

Senior Lecturer

\section{Оксана Бровкіна}

кандидат філологічних наук, старший викладач

\section{Svitlana Baranova}

Ph.D. in Philology,

Assistant Professor

\section{Світлана Баранова}

кандидат філологічних наук, доцент

\footnotetext{
E-mail: s.baranova@gf.sumdu.edu.ua orcid.org/0000-0001-9425-9774

Researcher ID: M-5567-2018
}

Sumy State University

2, Rymskogo-Korsakova Str.,

Sumy, Ukraine, 40007
Сумський державний університет вул. Римського-Корсакова, 2, м. Суми, Україна, 40007

Original manuscript received July 26, 2018

Revised manuscript accepted March 06, 2019

\section{ABSTRACT}

The article presents the investigation of the main communicative characteristics of the English family discourse considering some psycholinguistic aspects. The investigation was based on the discourse fragments which were microdialogues between family members selected from literary works of the XX - beginning of the XXI century by means of continuous sampling. The scientists' views concerning the peculiarities of communication in the family were analyzed. The research is theoretically based on the modern linguistic approaches to the study of the discourse as a complex versatile phenomenon. 
The article treats the family discourse as the communicative interaction of the speakers related by family (marital and consanguineous) ties, connected spiritually, by common household and mutual moral responsibility. It is found out that the discourse under investigation is characterized by such communicative characteristics as dialogicality, addressability, spontaneity, situationality, everyday character and informality. The communication in the family acquires a dialogical form. The interaction takes place through the direct contact of the speakers that are keenly conscious of the circumstances in which the communication proceeds. The content of the family dialogical speech can be understood when the situation in which it is developing is considered. There is a distinct correlation between the dialogical speech and the situation whose external circumstances can be absent at the moment of speech, but they are implied in the interlocutors' consciousness and definitely reflected in it. Speech behaviour of each dialogue participant is greatly determined by partner's speech behaviour, his/her psychological state, character and breeding. The interaction of the relatives displays the absence of the strict regulation of literary norms, arbitrary choice of lexical units, breach of normative speech rules, use of deictic means. The necessity to study the family discourse regarding a communicative situation that presupposes the notions of dominating strategy and tactics is focused on.

Key words: family discourse, dialogicality, addressability, spontaneity, situationality, informality.

\section{Вступ}

Інтеграція України в європейський простір вимагає ознайомлення 3 особливостями економічного, політичного та соціального векторів життя європейців. У цих умовах актуальності набуває дослідження проблем сім’ї, родинних цінностей, що становить теоретичний інтерес для соціальної філософії, соціології, історії, психології, психолінгвістики, мовознавства, інших гуманітарних наук та має практичну цінність у процесі мовленнєвого спілкування, продукування і сприймання висловлювання, формування лінгвістичної, мовленнєвої й комунікативної компетенції мовців.

У вивченні родинного спілкування увага дослідників зосереджена на раціональній аргументативній комунікативній діяльності (Фадєєва, 2000), змінах сімейних формацій сучасності (Бігарі, 2006), конфліктній і кооперативній мовленнєвій взаємодії в рамках симетричних / асиметричних стосунків (Семенюк, 2007; Фролова, 2009), впливі гармонійності / дисгармонійності стосунків 
батьків на особистісний розвиток дитини (Чанцева-Коваленко, 2016). Розгляд англомовної сімейної комунікації відбувається 3 точки зору комунікативних стратегій і тактик (маритальний дискурс (Зимич, 2011), парентальний дискурс (Козлова, 2012)).

Спілкування в родині як складній багатофункціональній системі, що виконує взаємозалежні економічну, господарськопобутову, репродуктивну, виховну функції, розгортається в дискурсивному контексті, який являє собою єдність соціальних, психологічних, прагматичних характеристик дискурсу, поєднуючи в єдиний ланцюжок реальний світ, свідомість і мовлення. Контекст дискурсу визначає, на що спрямовано прагматичний фокус, як реалізуються схеми комбінування й сценарії розгортання мовленнєвих актів, мовленнєвих ходів, мовленнєвих кроків у мовленнєвій події, послідовність самих мовленнєвих подій у дискурсі (Шевченко, 2011).

Метою даного дослідження є аналіз основних комунікативних характеристик дискурсу родинного спілкування 3 урахуванням психолінгвістичних особливостей. Його матеріалом слугували дискурсивні фрагменти - мікродіалоги спілкування між членами родини, виокремлені методом суцільної вибірки з художніх творів англомовних авторів XX - початку XXI століть.

\section{Методи та методики дослідження}

Методологічно дослідження спирається на досягнення вчених у галузі дискурсології (Бєлова, 2004; Карасик, 2010), лінгвопрагматики (Сусов, 2009; Фролова, 2009; Grice, 1975), логічної семантики (Frege, 1980), теорій мовленнєвої діяльності (Леонтьев, 2003), мовленнєвого впливу (Стернин, 2001), невербальної комунікації (Солощук, 2009) та психолінгвістики (Горелов \& Седов, 2004). Теоретичною базою дослідження обрана прагма-дискурсивна парадигма лінгвістичного знання (Бацевич, 2010; Безугла, 2007; Шевченко, 2011).

Комплексний аналіз дискурсу англомовного родинного спілкування передбачає інтегративне застосування загальнонаукових методів дослідження (спостереження, опису, індукції, дедукції, інтроспекції) та контекстуального, семантико-синтаксичного, дескриптивного й інтерпретаційного методів, кількісної обробки емпіричних даних. 


\section{Результати та дискусії}

Ідейні (ціннісні), феміністичні, економічні, соціальні та медичні чинники в сукупності сформували сучасну англомовну сім'ю, якій притаманне різноманіття сімейних формацій, у тому числі із симетричними міжособистісними стосунками, перенесення народження дітей на більш пізній період, а також зростання кількості розлучень.

Учені виокремлюють вісім різновидів сучасної англомовної сім'ї: нуклеарна (західноєвропейська, традиційна, буржуазна) сім'я (nuclear family, Western-European family, traditional family, bourgeois family), неотрадиційна сім'я (neo-traditional family), симетрична (егалітарна) сім'я (symmetrical family), сім'я раніше розлучених (remarried couples, blended family, combined family, reconstituted family), сім'я на вихідні (weekend family), громадянський шлюб (cohabitation, consensual unions), одноосібна сім'я (one household family), союз гомосексуалістів (gay / lesbian unions, same-sex marriage / partnership, single-sex unions) (Бігарі, 2006). Тому для носіїв англійської мови лексема family не позначає класичну сім'ю 3 двома батьками та їхніми нащадками (Бігарі, 2006: 13).

Велика кількість класифікацій дискурсу, запропонованих сучасними дослідниками, є наслідком того, що в основу таксономії покладено різні принципи. До того ж, дискурс $є$ однією 3 найактуальніших сфер лінгвістичних досліджень (Yemelyanova \& Baranova, 2017: 153), зокрема, його відтворення в перекладі, який виступає психосеміотичним явищем (Zasyekin, 2010).

Дискурс родинного спілкування (матримоніальний, парентальний, дискурс сіблінгів) виділяємо за соціальноситуативним параметром чи сферою функціонування (класифікація типів дискурсу I.С. Шевченко та О.І. Морозової (Шевченко \& Морозова, 2005)). Комунікація в родині $\epsilon$ центральною ланкою в побутовому дискурсі. Для спілкування в родинно-побутовій сфері типовими рисами $є$ іррелевантність офіційної регламентації комунікативної поведінки, невимушеність, концентрація на інтимному та широкий спектр тематики.

Аналіз дискурсивних фрагментів родинного спілкування, взятих із художньої літератури, свідчить, що комунікація у родині відбувається у формі діалогу (89\%), тобто для дискурсу родинного 
спілкування характерна діалогічність. Діалогу між членами родини притаманна своєрідна внутрішня спільність партнерів, наявність єдиного предмету бесіди та певної свободи обміну думками.

Дискурс родинного спілкування передбачає розуміння інтенцій комунікантів у діалозі. Процес і результат розуміння залежать не лише від текстових та смислових домінант, а й від апперцепції адресата, його суб'єктивного стану на момент рецепції, культурного та історичного контексту (Акімова \& Акімова, 2018: 38). Саме адекватне розуміння інтенцій співрозмовниками та реагування на них $є$ одним із організуючих моментів діалогу. Побудова діалогів родинного спілкування може бути як простою (лінійною), так i складною (розгалуженою). Інтенціональне узгодження реплік в родинному діалозі проявляється у двох варіантах: послідовне (у випадках лінійної інтенціональної організації) - приклад № 1 та відстрочене (при розгалуженій організації розмови) - приклад № 2 .

(1) Husband: 'Time certainly goes on, doesn't it?' he said unnecessarily.

Wife: 'It sure does.'

Husband: 'Would you like me to collect Craig from school today?' he offered. 'If you want to hang on here for a while?'

Wife: 'Thanks, but I've already made arrangements,' she said. 'My mum's collecting him today because I wasn't sure what time I would be back. I shall stay on here to help Phoebe clear up.'

Husband: 'Are you teaching?'

Wife: 'No, I cancelled everything for today,' she told him.

Husband: 'It was probably the best idea,' Arnie said to stop the conversation from flagging (P. Evans).

Прикладом послідовної організації реплік $є$ розмова осіб, що включає: а) розділове питання чоловіка Time certainly goes on, doesn't it? знаходить відповідь у репліці дружини It sure does; б) пропозицію Would you like me to collect Craig from school today? з боку адресанта - відмова з подякою thanks зі сторони адресата Thanks, but I've already made arrangements; в) питання 3 метою дізнатися, чи дружина ще зайнята Are you teaching? - конкретна відповідь комуніканта No, I cancelled everything for today - реакція мовця-чоловіка It was probably the best idea.

(2) Mother: 'What were their names?' 
Son: 'One was called Jill and one was called Joan. I don't know what their other names were. Joan's on the stage. She asked me if I couldn't get her an understudy in your next play.'

Mother: 'But those places aren't open till four... You pig. You filthy pig.'

Son: 'I say, about the understudy, is there any chance for Joan?'

Mother: 'Tell her to come and see me one day' (W.S. Maugham).

Відстрочена організація реплік у діалозі показана у фрагменті спілкування матері та сина. Розпитування адресанта про те, де був іiі син майже всю ніч, наштовхується на прохання 3 його боку щодо знайомої She asked me if I couldn't get her an understudy in your next play. Ігнорування мовцем поданого прохання змушує адресата експлікувати його ще один раз за допомогою загального питання I say, about the understudy, is there any chance for Joan?, після чого врешті-решт поступає відповідь - репліка матері у формі спонукального речення Tell her to come and see me one day.

Формуючись та розвиваючись у спілкуванні, стосунки людей $\epsilon$ одним із факторів, що визначають характер та хід комунікації: від того, як вони складаються, залежить структура діалогу, використані засоби, дистанція по відношенню до співрозмовника і саме бажання вести розмову (Зачесова, 2007: 46). 3 одного боку, взаємини людей мають символічно-смислову природу: психомоторні символи регулюють процес спілкування та поведінку в цілому, даючи змогу створювати образ партнера по комунікації і регулювати статутнорольові стосунки (Хміляр, 2017: 12). 3 іншого боку, взаємостосунки у сім’ї є соціальним конструктом, при якому можливі як позитивні, так і конфліктні взаємодіі. Аспект непорозуміння торкається $23 \%$ діалогів родинного спілкування. Під час комунікації членів родини, де мовці мають спільну апперцепційну базу i, як правило, націлені на збереження добрих стосунків, комунікативний провал і комунікативний саботаж - рідкісні явища. У випадках неправильного та неповного розуміння виникають непорозуміння серед комунікантів.

Непорозуміння бувають об'єктивного характеру, що пов'язані 3 різною поінформованістю, різницею у запасі знань (приклад № 3).

(3) Father: 'Don't let him keep running out!' Arthur shouted... 'What the devil are you doing, Simon? Keep his head straight.' 
Son: 'I can't, Daddy.' With difficulty, Simon pulled the pony to a stop. 'I don't think he wants to jump tonight. He can't see,' he panted, looking at his father helplessly.

Father: 'It's not what he wants. It's what you want. You'll never ride him if you don't remember that.'(M. Dickens).

Непорозуміння між комунікантами (батьком та його малолітнім сином) виникає через об'єктивні причини, адже недосвідчений адресат не має достатньо знань щодо управління поні в темряві. Емоційність мовлення 3 боку обізнаного адресанта підсилюється використанням вульгаризму What the devil are you doing?, імперативної конструкції Keep his head straight, речення умовного стану You'll never ride him if you don't remember that.

Інша група факторів, що спричиняє непорозуміння, суб'єктивні чинники, які пов'язані з неоднозначністю вираження чи установками комунікантів (приклад № 4).

(4) Mother: 'Why do lads of our age 'ave ter have labels? We know our name and address!' Tommy muttered, kicking disconsolately at the kitchen lino.

Son: His mother glared at him. 'I 'eard that, Tommy Ford! Just shurrup or I'll swing fer yer!' (L. Andrews).

Розмова між мовцями викликає непорозуміння, оскільки син бажає знати, навіщо йому, маленькому хлопчику, табличка зі вказівкою на його ім'я на весіллі сестри (вербалізується за допомогою питального речення) Why do lads of our age 'ave ter have labels? Адресат сам підсилює своє питання окличним реченням We know our name and address, але адресант ігнорує запитання та відповідає погрозою, яка омовлюється умовним реченням Just shurrup or I'll swing fer yer!

Як бачимо, прояв психологічних факторів у відборі мовних форм пов'язаний із внутрішнім станом партнерів, настроєм, індивідуально-особистісними характеристиками мовців, зумовленими їхнім темпераментом та вихованням.

Діалогічному мовленню між членами англомовної родини притаманна зверненість: спілкування проходить у безпосередньому контакті мовців, добре обізнаних із умовами, у яких відбувається комунікація (приклад № 5).

(5) Mother: 'Kitty. How are you, dear?'

Daughter: 'I'm - fine... And you?'(K. O'riordan). 
У діалозі матері та доньки перша звертається до іншої використовуючи власну назву Kitty та ласкаво-пестливе слово dear.

Однією з найважливіших особливостей мовлення у дискурсі родинного спілкування $\epsilon$ його ситуативність. Невідомо, що скаже партнер на кожній стадії розвитку бесіди. Часто зміст родинного діалогу можна зрозуміти лише 3 урахуванням тієї ситуації, в якій воно здійснюється. Однак, самі зовнішні обставини ситуації можуть не бути наявними в момент мовлення, проте вони $є$ у свідомості комунікантів і обов'язково включені в неї як сформований у родині ідеальний образ особистості (Александровська, 2017: 15). Вони охоплюють минулі події (Greve, Cooper, Tibon \& Henson, 2019), відомі лише співрозмовникам, їхні переживання, життєвий досвід, спільну інформацію тощо (приклад № 6).

(6) Daughter: 'I still can't believe he's...'

Mother: '...Yes. Me too.' (K. O'riordan)

Мовці розмовляють про покійного батька; вони ще не можуть змиритися з тим, що його немає поруч I still can't believe he's..., хоча безпосередньо ім'я батька не вербалізується. Ситуація $\epsilon$ зрозумілою із контексту, а єдиним ключовим словом, що вказує на батька, є особовий займенник he. Неповнота висловлення не заважає комунікантам розуміти ситуацію.

Іншою визначальною комунікативною характеристикою діалогічного мовлення в дискурсі родинного спілкування $є$ його спонтанність, адже мовленнєва поведінка кожного учасника діалогу значною мірою зумовлена мовленнєвою поведінкою партнера. Нормальний темп мовлення вимагає швидкої реакції на репліки (приклад № 7).

(7) Daughter: 'Why did you marry my dad?'

She looked at me closely.

Mother: 'Don't be silly.'

Daughter: 'I'm not being silly.'

Mother: 'We had to have something for you, and besides, he's a good man, though I know he's not one to push himself. But don't you worry, you're dedicated to the Lord, I put you down for missionary school as soon as we got you. Remember Jane Eyre and St John Rivers' (J. Winterson).

Непідготовленість мовленнєвої дії 3 боку адресата на неочікуване інтимне запитання адресанта-доньки призводить до 
спонтанності у відповіді. Комунікант спочатку реагує невербально, використовуючи зоровий контакт she looked at me closely, а потім хоче відійти від теми та називає доньку негативно забарвленим словом silly у поєднанні $з$ наказовою конструкцією та негативною часткою not. Але заперечення адресанта щодо безглуздості питання I'm not being silly все ж таки змушує матір дати відповідь на питання, що свідчить про іiі незадоволеність шлюбом, дисгармонійність стосунків у сім’і, недостатній рівень їхньої емпатійної наповненості.

Основною лінгвальною формою реалізації міжособистісних сімейних стосунків $\epsilon$ розмовне мовлення - безпосереднє персональне спілкування, що передбачає ситуаційну зумовленість та спільність апперцепційної бази мовців (Осовська, 2010: 241). У розмовно-побутовому мовленні членів англомовної родини спостерігається відсутність чіткої регламентації літературних норм, довільність у відборі лексичних засобів (вживання діалектизмів, просторічних слів, вульгаризмів, жаргонізмів). Під впливом говірки, іншої мови, через незасвоєність літературної норми та 3 причин неуважного ставлення до побутового спілкування помітні відхилення від правильного чергування звуків, наголосу, вимови голосних або приголосних звуків (приклад № 8).

(8) Daughter: 'Oh, Pa,'Betsy protested. 'I'm not feelin' that well. Can I not just lie down fer a while? It's me ... well, yer know,» casting down her eyes and blushing. 'Just until we gerr under way.'

Fred, horribly embarrassed to be reminded of 'women's things', as he called them, backed off hastily, turning towards the steps that led to the deck.

Father: 'Yer know yer ma don't like ter leave pots an' things,' he mumbled (A. Howard).

У поданому діалозі мовців спостерігається повне порушення літературних норм: неправильна вимова (feelin', fe, yer, gerr, yer, ter замість feeling, for, you, get, you, to), помилкове використання граматичних видо-часових форм (I'm not feelin' that well замість I don't feel that good), неузгодженість підмета 3 присудком (yer ma don't like замість your ma does not like). Усі наявні девіації вказують як на певну неосвіченість мовців - членів родини, так i на недотримання літературних норм. 
Одним із маркерів дискурсу родинного спілкування, зумовлених його побутовістю, виступають неповні конструкції (приклад № 9).

(9) Daughter: 'Another baby?' Ellen was saying. 'Oh, that would be wonderful. Do let's have one, Mummy. Do let's.'

Mother: 'Would you like it?' Miriam smiled at her.

Daughter: 'More than anything in the world. Don't let's give our baby clothes to Aunt Anne.'

Mother: 'We'd better.' Miriam sighed. 'Run up and get them' (M. Dickens).

Спілкування комунікантів експлікується за допомогою декількох еліптичних конструкцій : 1) Another baby? - речення-питання, що не містить граматичних показників питання, але сприймається як квеситив (інформаційне питання) (Безугла, 2007: 108) та не має ні підмета, ні присудка; 2) We'd better - еліптичне речення без другорядних членів речення та повноцінного присудка.

Незважаючи на ряд еліпсисів, комунікація членів родини протікає успішно завдяки конструктивному принципу мовлення, який зводиться до максимальної шпаруватості, до передачі переважно того, що є в свідомості автора, не будучи прямо представлене в дійсності, до виділення однієї найсуттєвішої ознаки або зв'язку.

Так, у наступному дискурсивному фрагменті спілкування двох мовців обумовлюється короткими запитаннями, в яких зміст $€$ імпліцитним, на перший погляд, якщо не враховувати близькі родинні стосунки та обізнаність у спільних справах, і невеликими за об'ємом відповідями. Адресант використовує апосіопезу But what if...? i у цьому випадку невербалізованим залишається найважливіший концепт пропозиції. Важливість концепту, що замовчується, має комунікативний характер і пов'язана 3 властивістю апосіопези: перлокутивна ціль адресанта полягає у спробі подіяти на адресата таким чином, щоб той сам вивів імпліцитний смисл завдяки психологічному впливу на його думки, почуття та вчинки. Пор.:

Mother: 'But what if...?'

Daughter: 'I'll wait,' Mirrin said.

Mother: 'But why?'

Daughter: 'It's where I belong,' Mirrin answered (J. Stirling). 
Однією із особливостей спілкування мовців, пов'язаних родинними зв'язками, $\epsilon$ використання дейктичних засобів, що вказують на сприйняття учасниками спілкування простору, часу, один одного тощо, наприклад:

Mother: 'I know what it is,' Louise said soothingly. 'I've been through it, don't forget. I know it makes you jumpy.'

Daughter: 'You can't know.' Anne was determined to make a grievance of her pregnancy for the whole of its span. 'You can't possibly have felt like this, or you wouldn't have gone on having us. You don't know how ghastly I feel.'

Mother: 'Indeed, I do...' (M. Dickens).

Комуніканти під час спілкування використовують дейктичний елемент it. Значення поданого займенника $є$ зрозумілим лише для них, учасників побутової родинної розмови, та не спричиняє труднощів у розумінні та інтерпретації (дейксис it = pregnancy).

Мовлення у дискурсі родинного спілкування часто обмежується вказівкою на єдину експліцитну ознаку, пор.:

Father: 'Your mother was extremely distressed the other day when some young woman, claiming to be a friend of yours, gained admittance to our home... She was obviously not a lady, indeed had the manners and the vocabulary of a guttersnipe...'

Son: 'Before you go any further, or say anything else which might worsen the situation, let me tell you that Miss Pearce and I are to be married...'

Mother: 'Not in my home, she will not, 'his mother hissed, her face as cold and white and hard as the marble fireplace...' (A. Howard).

У поданому дискурсивному фрагменті батьки шанованого молодого чоловіка виказують йому невдоволення через візит дівчини не його класу She was obviously not a lady. Мовець, показуючи свою категоричність і негативне ставлення до стосунків сина 3 такими людьми, говорить лише одну фразу Not in my home, she will not, в якій лексема home включає і безпосереднє перебування в будинку разом, і стосунки за межами дому взагалі.

Аналізуючи психолінгвістичні особливості дискурсу родинного спілкування, варто звернути увагу на комунікативну ситуацію та комунікативний контекст. Комунікативна ситуація це складний комплекс зовнішніх умов спілкування та внутрішніх станів комунікантів, що представлені в мовленнєвій поведінці - 
висловлюванні, дискурсі (Формановская, 2010: 42). У сучасній інтерпретації модель комунікативної ситуації включає адресанта, адресата, безпосередньо повідомлення 3 його мовним кодом, канал зв'язку, зворотній зв'язок, комунікативний контекст. Комунікативний контекст обіймає лише ті складові обставин спілкування, які безпосередньо впливають на характер комунікації. Він являє собою сукупність лише лінгвістично релевантних компонентів ситуації: на текст (мовлення) впливає те, як певні учасники представляють, розуміють та якимось чином конструюють доречні для них характеристики ситуації.

Під час спілкування членів англомовної родини виникають різноманітні комунікативні ситуації. Кількісний аналіз дискурсивних фрагментів показує що найбільш поширеними виступають комунікативна ситуація відвертого спілкування (31\%), комунікативна ситуація утішання (24\%) та комунікативна ситуація непорозуміння (37\%) (Бровкіна, 2015).

Комунікація стратегічна за своєю суттю, оскільки спілкування не відбувається без мети. Стратегія представляє собою когнітивний план спілкування, за допомогою якого контролюється оптимальне вирішення комунікативних задач адресанта в умовах недостатньої інформації про дії партнера (Иссерс, 2006: 100). У кожній комунікативній ситуації родинного спілкування домінують певні стратегії, зокрема, стратегія відвертості в ситуації відвертого спілкування, стратегія утішання в ситуації утішання, стратегії конфліктування та примирення в ситуації непорозуміння (Бровкіна, 2015). Комунікативна стратегія характеризується певним набором комунікативних тактик i дій. Комунікативні дії вибудовуються на нейропсихологічному, психоперцептивному, психолінгвістичному та соціально-психологічному рівнях (Гончарук \& Онуфрієва, 2018).

Мовленнєва діяльність людини - це рольова діяльність. Роль $\epsilon$ стійким шаблоном поведінки, що включає в себе дії, думки та почуття людини, а сімейні ролі - це результат накладання та синкретизму різноманітних ролей (ієрархічних, психологічних, ініціативних), які виконують члени родини, та мають своє мовленнєве вираження в сфері родинної комунікації. Темою окремих дискусій може стати вивчення ситуативно-психологічних ролей, які залежать від типу симетричних / асиметричних стосунків 
мовців, та соціальних ролей чоловіка, дружини, батьків, дітей в найрізноманітніших адресантно-адресатних конфігураціях.

\section{Висновки}

Дискурс родинного спілкування - це комунікативна взаємодія мовців, споріднених родинними (шлюбними чи кровними) зв'язками, що характеризується діалогічністю, зверненістю, ситуативністю, спонтанністю, побутовістю та неформальністю. Йому притаманні комунікативні ситуації відвертого спілкування, утішання, непорозуміння. Психолінгвістичні особливості досліджуваного дискурсу полягають у спільності апперцепційної бази мовців, у кореляції психологічних факторів під час відбору мовних форм iз внутрішнім станом партнерів, настроєм, втомою, зайнятістю іншими справами тощо. У схожих ситуаціях мовці дотримуються неоднакових мовленнєвих стратегій, що зумовлено відмінностями в їхніх особистісних характеристиках, детермінованих темпераментом i вихованням. Їхня мовленнєва діяльність передає емпатійну наповненість родинних взаємин.

Дискурс англомовного родинного спілкування характеризується багатоплановістю структурно-семантичного та комунікативнопрагматичного наповнення в умовах реалізації мовленнєвого впливу в тій чи іншій комунікативній ситуації. Тому перспективними, на нашу думку, можуть бути міждисциплінарні студії родинного дискурсу 3 такими галузями, як психолінгвістика мовленнєвого впливу, психолінгвістика комунікації й мовленнєвого спілкування, психолінгвістика перекладу, психолінгвістика білінгвізму та багатомовності тощо.

\section{Література}

Акімова Н., Акімова А. Розуміння тексту як специфічний вид розуміння. Psycholinguistics. Психолінгвістика. Психолингвистика. 2018. Вип. 24(1). C. 27-46. https://doi.org/10.31470/2309-1797-2018-24-1-27-46

Александровська В.М. Психологія ідеального образу : автореф. дис. ... докт. психол. наук : 19.00.01. Київ, 2017. 39 с.

Бацевич Ф.С. Нариси з лінгвістичної прагматики. Львів : ПАІС, 2010. 336 с.

Безугла Л.Р. Вербалізація імпліцитних смислів у німецькомовному діалогічному дискурсі. Харків : ХНУ імені В.Н. Каразіна, 2007. 332 с. 
Бєлова А.Д. Комунікативні стратегії і тактики: проблеми систематики. Мовні $i$ кониептуальні картини світу. Київ, 2004. С 11-16.

Бігарі А.А. Дискурс сучасної англомовної сім’ї : дис. ... канд. філол. наук : 10.02.04. Київ, 2006. 225 с.

Бровкіна О.В. Стратегії англомовного родинного дискурсу в ситуаціях відвертого спілкування, утішання, непорозуміння : автореф. дис. ... канд. філол. наук : 10.02.04. Харків, 2015. 20 с.

Гончарук Н., Онуфрієва Л. Психологічний аналіз рівнів побудови комунікативних дій. Psycholinguistics. Психолінгвістика. Психолингвистика. 2018. Вип. 24(1). C. 97-117. https://doi.org/10.31470/2309-1797-2018-24-1-97-117

Горелов И.Н., Седов К.Ф. Основы психолингвистики. Москва : Лабиринт, 2004. 304 c.

Зачесова И.А. Особенности взаимопонимания в семейном диалоге. Общение $u$ познание. Москва, 2007. 495 с.

Зимич С.В. Структурно-семантичні і прагматичні особливості маритального діалогічного дискурсу : автореф. дис. ... канд. філол. наук : 10.02.04. Харків, 2011. $20 \mathrm{c}$.

Иссерс О.С. Коммуникативные стратегии и тактики русской речи. Москва : Ком книга, 2006. 228 с.

Карасик В.И. Языковой круг : личность, концепты, дискурс. Волгоград : Перемена, 2010. 492 с.

Козлова В.В. Реалізація виховного впливу в англомовному парентальному дискурсі: структурно-семантичний та прагматичний аспекти : автореф. дис. ... канд. філол. наук : 10.02.04. Харків, 2012. 20 с.

Леонтьев А.А. Психолингвистические единицы и порождение речевого высказывания. Москва : Эдиториал УРСС, 2003. 307 с.

Осовська I.M. Стратегії і преферентні тактики парентального німецькомовного дискурсу. Наукові записки. 2010. Вип. 16. С. 240-246.

Семенюк А.А. Гендерні та вікові особливості кооперативної мовленнєвої поведінки в сімейному дискурсі (на матеріалі сучасної англійської мови) : автореф. дис. ... канд. філол. наук : 10.02.04. Донецьк, 2007. 22 с.

Солощук Л.В. Взаємодія вербальних і невербальних компонентів комунікації у сучасному англомовному дискурсі : автореф. дис. ... док. філол. наук : 10.02.04. Київ, 2009. 40 с.

Стернин И.А. Введение в речевое воздействие. Воронеж : Полиграф, 2001. 252 с.

Сусов И.П. Лингвистическая прагматика. Винница : НОВА КНИГА, 2009. 272 с.

Фадєєва О.В. Стратегії і тактики конфліктного дискурсу : автореф. дис. ... канд. філол. наук : 10.02.04. Київ, 2000. 20 с.

Формановская Н.И. Культура общения и речевого поведения. Москва : ИКАР, 2010. 237 c.

Фролова I.Є. Стратегія конфронтації в англомовному дискурсі. Харків : ХНУ імені В.Н. Каразіна, 2009. 344 с.

Хміляр О.Ф. Психологія символічної регуляції поведінки особистості : автореф. дис. ... докт. психол. наук : 19.00.01. Київ, 2017. 41 с.

Чанцева-Коваленко О.М. Гармонійні стосунки батьків як чинник особистісного розвитку дитини : автореф. дис. ... канд. психол. наук : 19.00.01. Київ, 2016. 22 c.

Шевченко I.C., Морозова О.І. Дискурс як мисленнєво-комунікативна діяльність. Дискурс як когнітивно-комунікативний феномен. Харків, 2005. С. 21-28. 
Шевченко І.С. Дискурс и его категории. Вісник Харківського національного університету ім. В.Н. Каразіна. 2011. Вип. 973(68). С. 6-12.

Frege, G. (1980). Über Sinn und Bedeutung. Funktion, Begriff, Bedeutung (pp. 4065). Göttingen: Vandenhoek.

Greve, A., Cooper, E., Tibon, R., \& Henson, N.R. (2019). Knowledge is power: Prior knowledge aids memory for both congruent and incongruent events, but in different ways. Journal of Experimental Psychology: General, 148(2), 325-341. https://doi.org/10.1037/xge0000498

Grice, H.P. (1975). Logic and conversation. Syntax and Semantics, 3, 41-52.

Yemelyanova, O.V., \& Baranova, S.V. (2017). Ukraine's image verbalisation in modern English mass media discourse. Advance Research Journal of Multi-Disciplinary Discoveries, 18.0(XI), 52-57.

Zasyekin, S. (2010). Translation as a psycholinguistic phenomenon. Journal of Psycholinguistic Research, 39(3), 225-234. https://doi.org/10.1007/s10936-0099134-2

\section{Джерела}

Andrews, L.A. (2006). Wing and a Prayer. London: Headline Book Publishing.

Dickens, M. (1977). The Winds of Heaven. London: Penguin Books.

Evans, P.A. (1998). Song in Your Heart. London: Headline Book Publishing.

Howard, A. (2003). Painted Highway. London: Hodder and Stoughton.

Maugham, W.S. (2002). Theatre. Vinnytsia: Nova Knyha.

O'riordan, K. (1995). Involved. London: Harper Collins Publishers.

Stirling, J. (1977). The Spoiled Earth. London: Pan Books.

Winterson, J. (1990). Oranges are not the Only Fruit. London: Pandora.

\section{References}

Akimova, N., \& Akimova, A. (2018). Rozuminnia tekstu yak spetsyfichnyi vyd rozuminnia [Text understanding as a special kind of understanding]. Psykholinhvistyka - Psycholinguistics, 24(1), 27-46. https://doi. org/10.31470/2309-1797-2018-24-1-27-46 [in Ukrainian].

Alexandrovska, V.N. (2017). Psykhologiia idealnoho obrazu [Psychology of the ideal self]. Extended abstract of Doctor's thesis. Kyiv [in Ukrainian].

Batsevych, F.S. (2010). Narysy z lingvistychnoii prahmatyky [An outline of linguistic pragmatics]. Lviv: PAIS [in Ukrainian].

Bezugla, L.R. (2007). Verbalizatsiia implitsytnykh smysliv u nimetskomovnomu dialogichnomu dyskursi [Verbalization of implicit senses in the German dialogical discourse]. Kharkiv: KhNU imeni V.N. Karazina [in Ukrainian].

Bielova, A.D. (2004). Komunikatyvni strategiii i taktyky: problemy systematyky [Communicative strategies and tactics: problems of systematics]. Movni $i$ kontseptualni kartyny svitu - Language and conceptual pictures of the world (pp. 11-16). Kyiv: Logos [in Ukrainian].

Bihari, A.A. (2006). Diskurs suchasnoii anhlomovnoii simii [Discourse of the modern English family]. Candidate's thesis. Kyiv [in Ukrainian]. 
Brovkina, O.V. (2015). Strategiii anhlomovnoho rodynnoho dyskursu v sytuatsiiah vidvertoho spilkuvannia, utishannia, neporozuminnia [Strategies of the English family discourse in the situations of frank communication, consolation, misunderstanding]. Extended abstract of Candidate's thesis. Kharkiv [in Ukrainian].

Honcharuk, N., \& Onufriieva, L. (2018). Psykhologichnyi analiz rivniv pobudovy komunikatyvnykh dii [Psychological analysis of levels of communicative actions construction]. Psykholinhvistyka - Psycholinguistics, 24(1), 97-117. https://doi. org/10.31470/2309-1797-2018-24-1-97-117 [in Ukrainian].

Gorelov, I.N., \& Sedov, K.F. (2004). Osnovy psykholingvistiki [Fundamentals of psycholinguistics]. Moscow: Labirint [in Russian].

Zachesova, I.A. (2007). Osobiennosti vzaimoponimaniia v semeinom dialogie [Peculiarities of mutual understanding in the family dialogue]. In V.A. Barabanshchikov \& Ye.S. Samoilienko (Eds.), Obshcheniie i poznaniie Communication and cognition (pp. 45-51). Moscow: Institut psikhologii RAN [in Russian].

Zymych, Ye.V. (2011). Strukturno-semantychni i prahmatychni osoblyvosti marytalnoho dialohichnoho dyskursu [Structural-semantic and pragmatic peculiarities of the marital dialogical discourse]. Extended abstract of Candidate's thesis. Kharkiv: V.N. Karazin Kharkiv National University [in Ukrainian].

Issers, O.S. (2006). Kommunikativnyie strategii i taktiki ruskoi riechi [Communicative strategies and tactics of the Russian speech]. Moscow: Kom kniga [in Russian].

Karasik, V.I. (2010). Yazykovoi krug: lichnost, kontsepty, diskurs [Language circle: personality, concept, discourse]. Volgograd: Pieriemiena [in Russian].

Kozlova, V.V. (2012). Realizatsiia vykhovnoho vplyvu v anhlomovnomu dyskursi: strukturno-semantychnyi ta prahmatychnyi aspekty [Realization of educational influence in the English parental discourse: structural-semantic and pragmatic aspects]. Extended abstract of Candidate's thesis. Kharkiv: V.N. Karazin Kharkiv National University [in Ukrainian].

Leontiev, A.A. (2003). Psikholingvisticheskiie yedinitsy $i$ porozhdeniie rechevogo vyskazyvaniia [Psycholinguistic units and derivation of a speech utterance]. Moscow: Editorial [in Russian].

Osovska, I.M. (2010). Strategii i preferentni taktyky parentalnohoh nimetskomovnoho dyskursu [Strategies and preferential tactics of the parental German discourse]. Naukovi zapysky - Scientific Notes, 16, 240-246 [in Ukrainian].

Semeniuk, A.A. (2007). Henderni ta vikovi osoblyvosti kooperatyvnoii movlennievoii povedinky $\mathrm{v}$ simeinomu dyskursi (na materiali suchasnoii anhliiskoii movy) [Gender and age peculiarities of cooperative speech behavior in the family discourse (on the material of the modern English)]. Extended abstract of Candidate's thesis. Donetsk: Donetsk National University [in Ukrainian].

Soloshchuk, L.V. (2009). Vzaiemodiia verbalnykh i nevarbalnykh komponentiv komunikatsii u suchssnomu anhlomovnomu dyskursi [Interaction of verbal and non-verbal components of communication in the modern Enhglish discourse]. Extended abstract of Doctor's thesis. Kyiv: Taras Shevchenko Kyiv National University [in Ukrainian].

Sternin, I.A. (2001). Vvedeniie v riechievoie vozdeistviie [Introduction into speech interaction]. Voronezh: Poligraf [in Russian].

Susov, I.P. (2009). Lingvisticheskaia pragmatika [Lingusitic pragmatics]. Vinnytsia: Nova Knyha [in Russian]. 
Fadieieva, O.V. (2000). Strategii i taktyky konfliktnoho dyskursu [Strategies and tactics of the conflict discourse]. Extended abstract of Candidate's thesis. Kyiv: Kyiv State Linguistic University [in Ukriaian].

Formanovskaia, N.I. (2010). Kultura obshcheniia i riechevogo poviedieniia [Culture of communication and speech behaviour]. Moscow: IKAR [in Russian].

Frolova, I.Ye. (2009). Startegiia konfrontatsii v anhlomovnomu dyskursi [Confrontation strategy in the English discourse]. Kharkiv: V.N. Karazin Kharkiv National University [in Ukrainian].

Hmiliar, O.F. (2017). Psykhologiia symvolichnoi reguliatsii povedinky osobystosti [Psychology of the symbolic regulation of the behavior of a personality]. Extended abstract of Doctor's thesis. Kyiv: G.S. Kostiuk Institute of Psychology of the NAPS of Ukraine [in Ukrainian].

Chantseva-Kovalenko, E.N. (2016). Harmoniini stosunky batkiv yak chynnyk osobystisnoho rozvytku dytyny [Parents' harmonious relationships as a factor of the personal development of the child]. Extended abstract of Doctor's thesis. Kyiv: G.S. Kostiuk Institute of Psychology of the NAPS of Ukraine [in Ukrainian].

Shevchenko, I.S., \& Morozova, O.I. (2005). Dyskurs yak myslennievo-komunikatyvna diialnist [Discourse as a thinking-communicative activity]. Dyskurs yak kohnityvno-komunikatyvnyi fenomen - Discourse as a cognitive-communicatve phenomenon (pp. 21-28). Kharkiv: Konstanta [in Ukrainian].

Shevchenko, I.S. (2011). Dyskurs i iego kategorii [Discourse and its categories]. Visnyk Kharkivskoho natsionalnoho universytetu im. V.N. Karazina - The journal of V.N. Karazin Kharkiv National University, 973(68), 6-12 [in Russian].

Frege, G. (1980). Über Sinn und Bedeutung. Funktion, Begriff, Bedeutung (pp. 4065). Göttingen: Vandenhoek.

Greve, A., Cooper, E., Tibon, R., \& Henson, N.R. (2019). Knowledge is power: Prior knowledge aids memory for both congruent and incongruent events, but in different ways. Journal of Experimental Psychology: General, 148(2), 325-341. https://doi.org/10.1037/xge0000498

Grice, H.P. (1975). Logic and conversation. Syntax and Semantics, 3, 41-52.

Yemelyanova, O.V., \& Baranova, S.V. (2017). Ukraine's image verbalisation in modern English mass media discourse. Advance Research Journal of Multi-Disciplinary Discoveries, 18.0(XI), 52-57.

Zasyekin, S. (2010). Translation as a psycholinguistic phenomenon. Journal of Psycholinguistic Research, 39(3), 225-234. https://doi.org/10.1007/s10936-0099134-2

\section{Sources}

Andrews, L.A. (2006). Wing and a Prayer. London: Headline Book Publishing.

Dickens, M. (1977). The Winds of Heaven. London: Penguin Books.

Evans, P.A (1998). Song in Your Heart. London: Headline Book Publishing.

Howard, A. (2003). Painted Highway. London: Hodder and Stoughton.

Maugham, W.S. (2002). Theatre. Vinnytsia: Nova Knyha.

O'riordan, K. (1995). Involved. London: Harper Collins Publishers.

Stirling, J. (1977). The Spoiled Earth. London: Pan Books.

Winterson, J. (1990). Oranges are not the Only Fruit. London: Pandora. 


\section{АНОТАЦІЯ}

У статті представлено результати дослідження основних комунікативних характеристик англомовного дискурсу родинного спілкування з урахуванням психолінгвістичних аспектів. Дослідження проводилося на основі дискурсивних фрагментів, що являють собою мікродіалоги між членами родини, виокремлених методом суцільної вибірки з художніх творів авторів XX - початку XXI століття. Проаналізовано погляди вчених щодо проблеми особливостей комунікації в сім'ї. Теоретично дослідження спирається на сучасні лінгвістичні підходи до розуміння дискурсу як складного багатопланового феномена.

Дискурс родинного спілкування тлумачиться в статті як комунікативна взаємодія мовців, споріднених родинними (шлюбними чи кровними) зв'язками, пов'язаних духовно, спільністю побуту та взаємною моральною відповідальністю. З'ясовано, що для досліджуваного дискурсу характерні такі комунікативні характеристики, як діалогічність, зверненість, ситуативність, спонтанність, побутовість та неформальність. Комунікація в родині відбувається у формі діалогу. Спілкування проходить у безпосередньому контакті мовців, добре обізнаних із умовами, у яких відбувається комунікація. зміст родинного діалогічного мовлення можна зрозуміти лише з урахуванням тієї ситуації, в якій воно здійснюється. Існує чітка співвіднесеність діалогічного мовлення з ситуацією, зовнішні обставини якої можуть у момент мовлення не бути наявними, проте вони $\epsilon$ у свідомості комунікантів і обов'язково включені в неї. Мовленнєва поведінка кожного учасника діалогу значною мірою зумовлюється мовленнєвою поведінкою партнера, його/ії психологічним станом, темпераментом. вихованням. У спілкуванні мовців, пов'язаних родинними зв'язками, спостерігається відсутність чіткої регламентації літературних норм, довільний відбір лексичних одиниць, порушення нормативних правил мовлення, використання дейктичних засобів.

Закцентовано увагу на необхідності розгляду дискурсу родинного спілкування з огляду на комунікативні ситуації, що передбачає звернення до понять стратегії, яка домінує у певних ситуаціях, та тактики.

Ключові слова: дискурс родинного спілкування, діалогічність, зверненість, ситуативність, спонтанність, неформальність.

\section{Бровкина Оксана, Баранова Светлана. Семья vs дискурс}

\section{АННОТАЦИЯ}

В статье представлены результаты исследования основных коммуникативных характеристик англоязычного дискурса семейного общения с учетом психолингвистических аспектов. Исследование проводилось на основе дискурсивных фрагментов, выделенных методом сплошной выборки из художественных произведений авторов XX - начала XXI века. Проанализированы взгляды ученых на проблемы особенностей коммуникации в семье. Теоретически исследование опирается на современные лингвистические подходы к пониманию дискурса как сложного многопланового френомена. 
Дискурс семейного общения интерпретируется в статье как коммуникативное взаимодействие говорящих, объединённых родственными (брачными или кровными) узами, связанных духовно, общностью быта и взаимной моральной ответственностью. Определено, что для исследуемого дискурса характерны такие коммуникативные характеристики, как диалогичность, обращенность, ситуативность, спонтанность, бытовой характер и неформальность. Коммуникация в семье осуществляется в форме диалога. Общение происходит при непосредственном контакте говорящих, хорошо осведомленных с условиями, в которых протекает коммуникация. Содержание семейной диалогической речи можно понять только с учетом той ситуации, где она произносится. Существует четкая соотнесённость диалогчческой речи с ситуацией, внешние обстоятельства которой могут отсутствовать в момент речи, но они присутствуют в сознании коммуникантов и обязательно включены в него. Речевое поведение каждого участника диалога во многом обусловлено речевым поведением партнёра, его/ ее психологическим состоянием, темпераментом, воспитанием. В общении говорящих, связанных родственными узами, наблюдается отсутствие четкой регламентации литературных норм, произвольный отбор лексических единии, нарушение нормативных правил речи, использование дейктических средств.

Сделано акцент на необходимости рассмотрения дискурса семейного общения с точки зрения коммуникативной ситуации, предусматривающей обращение к понятиям стратегии, которая доминирует в определенных ситуациях, и тактики.

Ключевые слова: дискурс семейного общения, диалогичность, обращенность, ситуативность, спонтанность, неформальность. 